\title{
Complement inhibition by gram-positive pathogens: molecular mechanisms and therapeutic implications
}

\author{
Alexander Laarman • Fin Milder • Jos van Strijp • \\ Suzan Rooijakkers
}

Received: 23 September 2009 /Revised: 25 November 2009/Accepted: 27 November 2009/Published online: 9 January 2010

(C) The Author(s) 2010. This article is published with open access at Springerlink.com

\begin{abstract}
The plasma proteins of the complement system are essential in the innate immune response against bacteria. Complement labels bacteria with opsonins to support phagocytosis and generates chemoattractants to attract phagocytes to the site of infection. In turn, bacterial human pathogens have evolved different strategies to specifically impair the complement response. Here, we review the large arsenal of complement inhibitors produced by the gram-positive pathogens Staphylococcus aureus and Group A Streptococcus. We discuss how these bacterial molecules provide us with new tools to treat both infectious and inflammatory disease conditions in humans.
\end{abstract}

Keywords Complement - Immune evasion · Bacteria · Innate immunity

The innate immune system plays a critical role in our host defense against invading pathogens. This system consists of three different parts: (a) the complement system, (b) phagocytes, and (c) antimicrobial peptides. The three major functions of the complement cascade in innate immunity are (1) to label pathogens or immunogenic particles with $\mathrm{C} 3 \mathrm{~b}$ and $\mathrm{iC} 3 \mathrm{~b}$ to facilitate phagocytic uptake via complement receptors, (2) to attract phagocytes by producing chemoattractant C5a, and (3) to directly lyse gram-negative

A. Laarman $\cdot$ F. Milder $\cdot$ J. van Strijp $\cdot$ S. Rooijakkers $(\bowtie)$

Medical Microbiology, University Medical Center Utrecht,

PO G04.614, Heidelberglaan 100,

3584 CX Utrecht, the Netherlands

e-mail: s.h.m.rooijakkers@umcutrecht.nl

S. Rooijakkers

Departments of Pediatrics, University of California,

San Diego, CA, USA bacteria through membrane attack complex (MAC; C5b-9) formation (Fig. 1) [1]. Complement is initiated by two specific recognition pathways, the classical and lectin pathway, which are amplified by the alternative pathway. All three pathways converge at the formation of the $\mathrm{C} 3$ convertases. These bimolecular surface-bound enzyme complexes catalyze the key reaction in complement activation: cleavage of complement protein $\mathrm{C} 3$ into $\mathrm{C} 3 \mathrm{a}$, a chemoattractant with bactericidal activity [2-4], and C3b [5]. Convertase formation is pivotal in complement activation since $\mathrm{C} 3 \mathrm{~b}$ and its inactive derivative $\mathrm{iC} 3 \mathrm{~b}$ facilitate phagocytosis. Furthermore, the deposited $\mathrm{C} 3 \mathrm{~b}$ can form new convertases, thereby amplifying the opsonization process. Subsequently, the high concentrations of locally deposited $\mathrm{C} 3 \mathrm{~b}$ induce a shift in substrate specificity of the convertase to complement protein $\mathrm{C} 5$. The cleavage products of $\mathrm{C} 5$ are $\mathrm{C} 5 \mathrm{a}$, a potent chemoattractant, and $\mathrm{C} 5 \mathrm{~b}$ that initiates the lytic pathway. Due to the resulting C5a gradient, neutrophils migrate toward the site of infection and phagocytose the invaders. Neutrophils kill ingested particles intracellularly by the production of reactive oxygen species and the release of granule constituents such as proteolytic enzymes and antimicrobial peptides. These peptides are also released into the extracellular space to kill microorganisms extracellularly [6]. Together, these complement-mediated events are responsible for the efficient elimination of invading bacteria.

It has become increasingly evident that pathogens have developed various ways to evade the constant attack of the complement system. Pathogens produce proteins that modulate all stages of the complement cascade. These proteins inhibit complement recognition and amplification, cleave complement proteins, or interfere with complement receptor interactions on phagocytes. A number of reviews have been published on these specific topics [7-9]. In this 


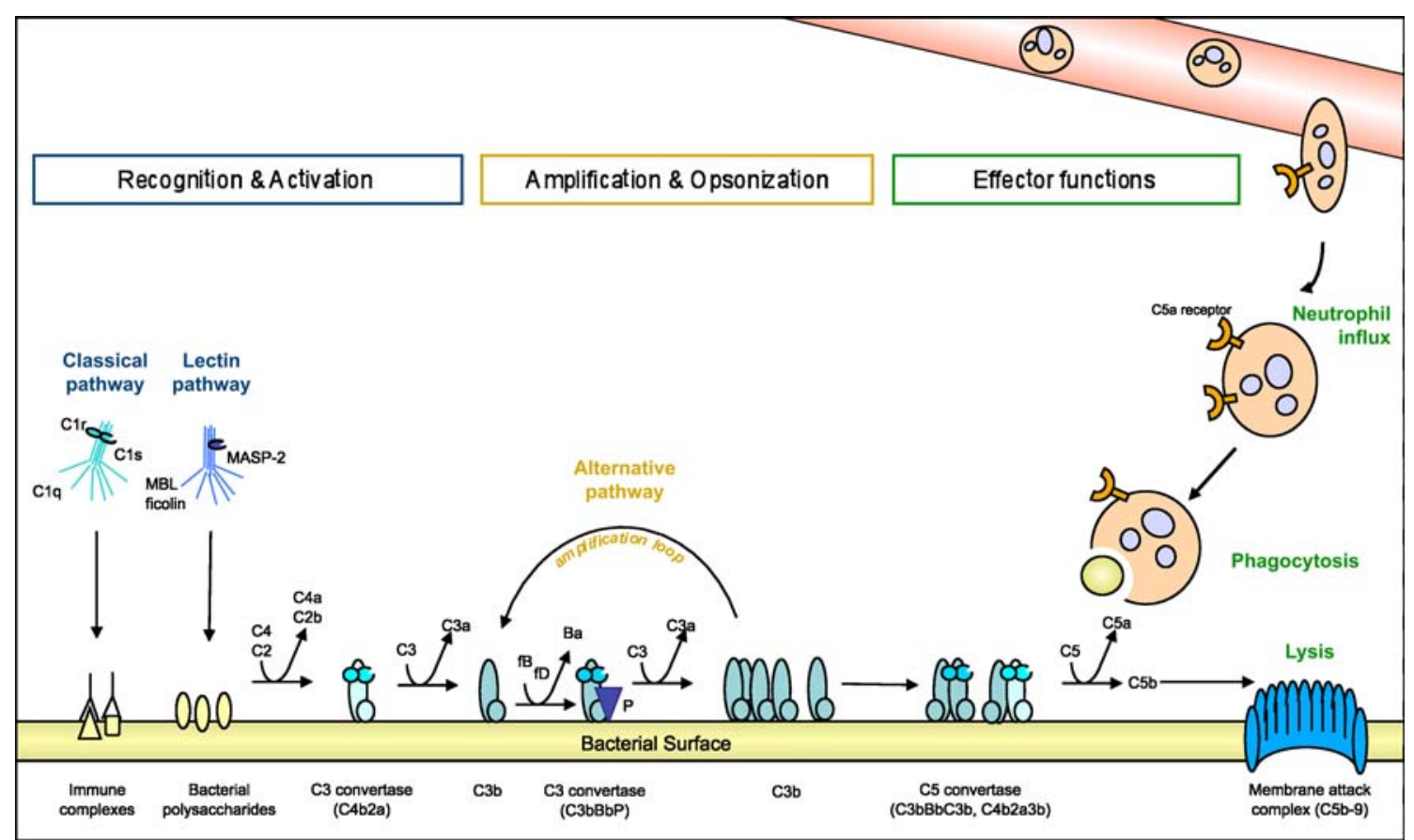

Fig. 1 Schematic overview of the complement system. The complement cascade is activated by recognition of microbe-bound antibodies or microbial sugars by the $\mathrm{C} 1$ complex $(\mathrm{CP})$ or the MBL- and ficolinMASP-2 complex (LP), respectively. Both C1s and MASP-2 cleave complement proteins $\mathrm{C} 4$ and $\mathrm{C} 2$ to generate the $\mathrm{CP} / \mathrm{LP} \mathrm{C} 3$ convertase: $\mathrm{C} 4 \mathrm{~b} 2 \mathrm{a}$. The Alternative Pathway (AP) $\mathrm{C} 3$ convertase $\mathrm{C} 3 \mathrm{bBb}$ is generated after binding of $\mathrm{fB}$ to surface-bound $\mathrm{C} 3 \mathrm{~b}$ and subsequent cleavage by $\mathrm{fD}$. The AP $\mathrm{C} 3$ convertase is stabilized by the positive regulator human properdin $[47,48]$. Both $\mathrm{C} 3$ convertases $(C 4 b 2 a$ and
$C 3 b B b$ ) cleave $\mathrm{C} 3$ into $\mathrm{C} 3 \mathrm{a}$ and $\mathrm{C} 3 \mathrm{~b}$. $\mathrm{C} 3 \mathrm{~b}$ covalently binds to bacterial surfaces, thereby amplifying complement activation through formation of new $\mathrm{C} 3$ convertases and contributes to phagocytosis, antigen presentation, and formation of $\mathrm{C} 5$ convertases $(C 4 b 2 a 3 b$ and $C 3 b B b 3 b)$. C5 convertases cleave $\mathrm{C} 5$ into the anaphylatoxin $\mathrm{C} 5 \mathrm{a}$, which attracts neutrophils to the site of infection, and $\mathrm{C} 5 \mathrm{~b}$, which forms a complex with complement proteins C6-C9 to generate the membrane attack complex

has been suggested to block binding of $\mathrm{C} 1 \mathrm{q}$ and subsequent activation of the classical pathway.

Another strategy to prevent recognition is to eliminate opsonic molecules from the bacterial surface by proteolytic degradation. Staphylokinase (SAK) is a secreted protein that binds and activates surface-bound plasminogen into plasmin, which may enhance bacterial invasion through host tissues. Interestingly, it has been shown that SAK is anti-opsonic as well. SAK-mediated plasmin deposition on the bacterial surface can cleave IgG and $\mathrm{C} 3 \mathrm{~b}$ and thereby inhibit phagocytosis in vitro [13]. GAS expresses several proteases that directly cleave IgG: the Endoglycosidase in Streptococcus pyogenes (EndoS) specifically hydrolyzes the asparagine-linked glycan in the $\mathrm{C}_{\mathrm{H}} 2$ domain of $\mathrm{IgG}$; the IgG-degrading enzyme of $S$. pyogenes (IdeS or Mac-1), Mac-2, and streptococcal pyrogenic exotoxin B (SpeB) all cleave $\operatorname{IgG}$ in the hinge region $[14,15]$.

\section{Modulation of complement amplification}

Formation of the $\mathrm{C} 3$ convertases is elemental for amplification of complement activation and downstream immune 


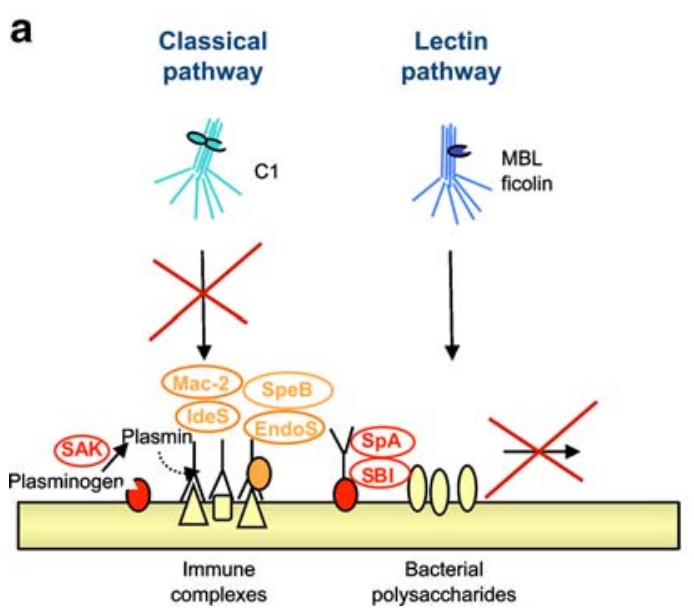

b

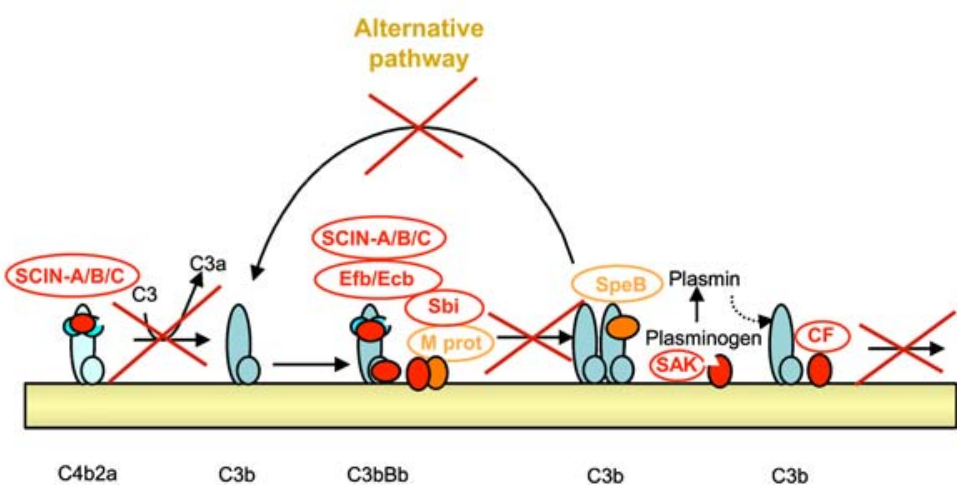

Fig. 2 Bacterial evasion of complement recognition (a) and opsonization (b). Illustrated are proteins of $S$. aureus (red) and GAS (yellow) that modulate complement recognition and opsonization. a To prevent recognition by the classical pathway, $S$. aureus expresses the surface proteins ProtA and Sbi. Both proteins bind the Fc tail of IgG preventing its interaction with FcR on neutrophils. Another mechanism to prevent recognition is by inactivating $\mathrm{IgG}$, either directly by proteases IdeS, Mac-2, and $\mathrm{SpeB}$, or indirectly by SAK-activated plasmin. b There are three ways by which $S$. aureus and GAS

modulate opsonization: (1) C3 cleavage; directly by SpeB or indirectly by SAK-mediated activated plasmin. ClfA binds human fI, thereby enhancing C3 cleavage. (2) Convertase modulation; S. aureus inactivates the $\mathrm{C} 3$ convertases by secreting SCIN, SCIN-B, SCIN-C, Efb, and Ecb. (3) Modulating host regulators; Sbi and the streptococcal M-protein bind the negative convertase regulators (human $\mathrm{FH}$, FHL1, C4BP, and CD46) while SpeB cleaves the positive convertase regulator, properdin

responses. There are three ways by which $S$. aureus and GAS modulate this central step in the complement cascade (Fig. 2b):

\section{Cleavage of $\mathrm{C} 3$}

The abundant GAS protease SpeB is, next to cleaving IgG, involved in breakdown of C3. Comparison of wild-type GAS and a SpeB knockout showed that SpeB blocks neutrophil recruitment to the site of infection and subsequent phagocytosis and bacterial clearance in vivo $[16,17]$. The $S$. aureus surface protein clumping factor A (ClfA) can bind the human $\mathrm{C} 3 \mathrm{~b}$ protease factor I (fI), thereby enhancing cleavage of surface-bound $\mathrm{C} 3 \mathrm{~b}$ into $\mathrm{iC} 3 \mathrm{~b}$ in vitro [18].

\section{Direct inactivation of $\mathrm{C} 3$ convertases}

Convertases are the major complement target among $S$. aureus immune evasion strategies. S. aureus secretes five different molecules that directly inhibit these central enzyme complexes. Staphylococcal complement inhibitor (SCIN) and its homologues SCIN-B and SCIN-C are highly effective $\mathrm{C} 3$ convertase inhibitors that block conversion of $\mathrm{C} 3$ and subsequent phagocytosis and $\mathrm{C} 5$ a formation in vitro at low concentrations [19]. The alternative pathway C3 convertase consists of a cofactor $(\mathrm{C} 3 \mathrm{~b})$ which is loosely bound to the protease subunit $(\mathrm{Bb})$. Recent structural studies revealed that the small $10-\mathrm{kD}$ SCIN protein fixates the convertase conformation and as such hampers a critical rearrangement of the protease subunit $\mathrm{Bb}$ in relation to substrate C3 $[20,21]$. The action of SCIN on the classical pathway convertase remains to be resolved but seems to be caused by a stabilizing mechanism as well [19]. Extracellular fibrinogen-binding protein (Efb) and extracellular complement-binding protein $(\mathrm{Ecb})$ can modulate the alternative pathway convertase by binding to the $\mathrm{C} 3 \mathrm{~b}$ molecule directly [22]. The crystal structures of both molecules in complex with the $\mathrm{C} 3 \mathrm{~d}$ domain of $\mathrm{C} 3$ have revealed their exact binding sites $[23,24]$. Interestingly, since the $\mathrm{C} 3 \mathrm{~d}$ fragment of $\mathrm{C} 3$ is involved in stimulation of adaptive immune responses, it was recently suggested that $\mathrm{Efb}$ functions as an adaptive immunity modulator as well [25].

\section{Binding or cleavage of human convertase regulators}

To protect host tissues from excessive complement activity, humans express complement regulators that downregulate convertase activity. A large number of pathogens express molecules that attract these regulators to their surface. The staphylococcal IgG-binding molecule Sbi has a diverse role in complement modulation. Next to its two IgGbinding domains, Sbi-III and IV, it can also bind to C3 [26]. Furthermore, Sbi binds the human complement regulators factor $\mathrm{H}(\mathrm{FH})$ and factor $\mathrm{H}$-related proteins and can form a stable tripartite complex with $\mathrm{C} 3$ and $\mathrm{FH}$ [27]. Altogether, these actions result in inhibition of the alternative pathway in vitro. The streptococcal $\mathrm{M}$ protein is a multifunctional surface molecule that binds four different human convertase regulators: $\mathrm{FH}$, factor $\mathrm{H}$ like-1 (FHL1), membrane cofactor protein (CD46), and C4-binding protein (C4BP). M protein consists of two polypeptide chains configured in an alphahelical coiled coil complex that is anchored to the cell membrane via its $\mathrm{C}$ terminus [28-30]. From the $\mathrm{N}$ to the $\mathrm{C}$ 
terminus, the protein comprises four repeat regions: hypervariable (a), variable (b), and conserved (c and d). Depending on the $\mathrm{M}$ type, the hypervariable region can bind $\mathrm{FH}$, FHL-1 [31], and C4BP [32]. By binding these complement regulators, $\mathrm{M}$ protein limits deposition of $\mathrm{C} 4 \mathrm{~b}$ and $\mathrm{C} 3 \mathrm{~b}$ increasing GAS resistance to phagocytosis [33]. In vivo studies with strains expressing mutated $\mathrm{M}$ protein indicate that protein is an important GAS virulent factor [34]. Finally, SpeB also digests the positive convertase regulator properdin, making the streptococci more resistant to neutrophil killing in vitro [35].

\section{Modulation of the complement effector functions: inhibiting $\mathrm{C} 5$ activation and neutrophil migration}

In the final step of the complement cascade, the $\mathrm{C} 5$ convertases cleave $\mathrm{C} 5$ to generate the important chemoattractant $\mathrm{C} 5 \mathrm{a}$ that directs neutrophils to the site of infection. S. aureus and GAS use various approaches to evade the C5a-mediated immune responses (Fig. 3). Staphylococcal superantigen-like 7 (SSL7) is a secreted protein that specifically binds to C5 [36] and thereby prevents $\mathrm{C} 5$ activation into $\mathrm{C} 5 \mathrm{~b}$ and $\mathrm{C} 5 \mathrm{a}$ in vitro (J. Bestebroer, personal communication). Efb and Ecb are very potent inhibitors of C5a responses in vitro and in vivo [22]. These molecules elicit their immune modulating capacity by binding the $\mathrm{C} 3 \mathrm{~b}$ part of the $\mathrm{C} 5$ convertase complex. GAS uses the cell-associated peptidase ScpA to directly target C5a. ScpA cleaves C5a and blocks chemotaxis of phagocytes toward the site of infection [37]. In a mouse pneumonia model, it was shown that the ScpA knockout mutant was less virulent than wild-type GAS [38]. Modulation of C5a responses by $S$. aureus proceeds through inhibition of the C5a receptor (C5aR). The chemotaxis inhibitory protein of S. aureus (CHIPS) is a $14-\mathrm{kD}$ excreted protein that effectively blocks neutrophil recruitment toward $\mathrm{C} 5 \mathrm{a}$ in vitro by binding the C5aR with high (nanomolar) affinity [39]. The recent nuclear magnetic resonance (NMR) structure of CHIPS in complex with the $\mathrm{N}$ terminus of the $\mathrm{C} 5 \mathrm{aR}$ showed two sulfated tyrosine (residues 11 and 14) of the C5aR to be essential for the interaction in between the $\mathrm{C} 5 \mathrm{aR}$ and the inhibitor CHIPS [40].

Cleavage of $\mathrm{C} 5$ also results in formation of $\mathrm{C} 5 \mathrm{~b}$, the molecule that initiates the formation of the membrane attack complex (C5b-9). This complex can damage target cells such as gram-negative bacteria. MAC formation is often monitored in vitro by a so-called hemolytic assay in which erythrocytes (often sheep or rabbit) are used as a direct target for complement activation and hemolysis. The $S$. aureus proteins SCIN, Efb, Ecb, and SSL7 block MAC-mediated erythrocyte hemolysis since they inhibit the complement cascade upstream of MAC formation. The highly variable strepto- coccal inhibitor of complement (SIC) from GAS was found to specifically block formation of the MAC by binding to the C5b-7 complex and preventing erythrocyte hemolysis in vitro [41]. The relevance of MAC inhibition by grampositive bacteria remains unclear since they are naturally protected from lysis via their thick cell wall. The SIC molecule also interacts with several human antimicrobial peptides (LL-37, defensins) [42], and this might be more relevant for protecting GAS from host immunity.

\section{Complement evasion molecules as tools and targets in therapy}

Bacterial complement modulators have important applications for the treatment of inflammatory diseases where complement is directed against our own cells [43]. Per definition, molecules that counteract acute innate immune

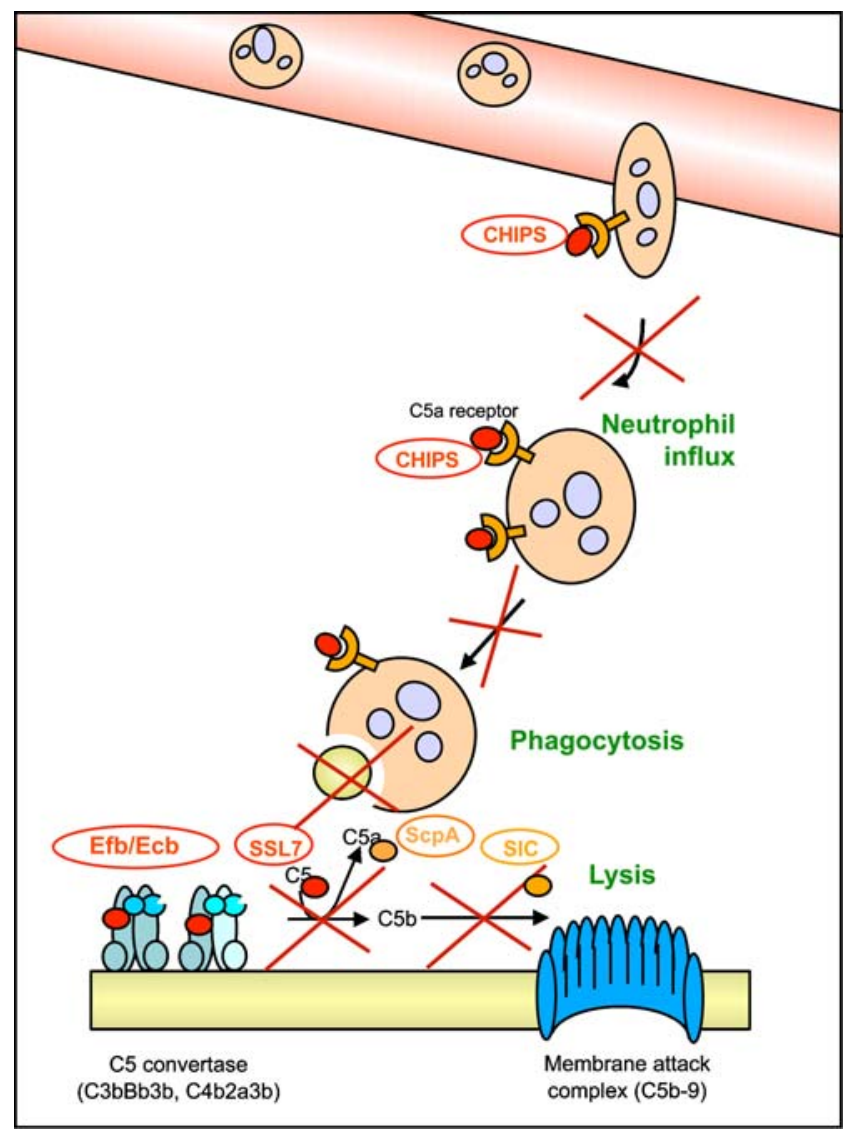

Fig. 3 Bacterial evasion of $\mathrm{C} 5$-mediated responses. Illustrated are proteins of S. aureus (red) and GAS (yellow) that modulate C5mediated responses. $\mathrm{Efb}$ and Ecb block the formation of $\mathrm{C} 5$ convertases and thereby inhibit C5a and MAC generation. SSL7 binds to $\mathrm{C} 5$ and prevents the cleavage of $\mathrm{C} 5$ into $\mathrm{C} 5 \mathrm{a}$ and $\mathrm{C} 5 \mathrm{~b}$. Neutrophil influx and phagocytosis are inhibited by CHIPS, which binds the $\mathrm{C} 5 \mathrm{aR}$, and ScpA that cleaves C5a. SIC inhibits the formation of the MAC, the final step in the complement cascade 
mechanisms are anti-inflammatory compounds. As opposed to several bacterial toxins, the high specificity and the mode of action that depends entirely on protein-protein interactions makes these nontoxic proteins suitable antiinflammatory drugs. It is tempting to speculate that these molecules could be used as injectables in acute inflammatory disorders. However, since these molecules are derived from common human pathogens, pre-existing antibodies severely complicate this approach. Furthermore, a number of the described molecules appear to be human-specific which complicates functional studies in vivo [19, 44, 45] However, the immunological molecules that are attacked by these factors might prove to be the essential targets to tackle in anti-inflammatory therapy. We feel that the bacterial products could be used as an indicator of the "Achilles heel" of the human immune system - almost at the atomic level. Especially, since the 3-D structures of a number of molecules in context with their target are now elucidated in several crystallographic and NMR studies [19, 20, 25, 40,46], this opens new possibilities for smart design of small-molecule therapeutics. Thus, we can copy these evolutionary-designed molecules to counteract the detrimental effects of complement activation in inflammatory disease states.

Next to their potential as anti-inflammatory compounds, we believe that targeting of complement evasion molecules should be included in future strategies to fight bacterial infections. The evasion molecules described above not only suppress natural immunity during an infection but also hamper the current attempts to create effective vaccines. The efficacy of vaccines is held back by the existing bacterial immune evasion strategies since they prevent neutrophils or complement to reach the site of infection. Even with sufficient opsonic or bactericidal antibodies on the bacterium, nothing will happen if the innate immune effectors are absent. Since immune evasion molecules are essentially vaccine evasion molecules, we propose that these molecules should be specifically targeted in the vaccine. Alternatively, we could think of ways to neutralize these molecules and use that in novel strategies to fight infectious diseases. In fact, we propose to inhibit the inhibitor and thereby decrease the advantage of the bacterium over the host.

So, taken together, the smart attack of the bacteria on our complement system might hold clues for future drugs in both inflammatory as well as infectious diseases. In this way, we could turn this powerful escape mechanism into our own advantage.

Acknowledgments A.L., J.v.S., and S.H.M.R. are supported by grants of the Netherlands Organization for Scientific Research (NWOTOP and NWO-Veni). S.H.M.R. is also funded by the European Molecular Biology Organization.
Conflict of interest statement The authors declare that they have no conflict of interests.

Open Access This article is distributed under the terms of the Creative Commons Attribution Noncommercial License which permits any noncommercial use, distribution, and reproduction in any medium, provided the original author(s) and source are credited.

\section{References}

1. Walport MJ (2001) Complement. First of two parts. N Engl J Med 344:1058-1066

2. Hartmann K, Henz BM, Krüger-Krasagakes S, Köhl J, Burger R, Guhl S, Haase I, Lippert U, Zuberbier T (1997) C3a and C5a stimulate chemotaxis of human mast cells. Blood 89:2863-2870

3. Daffern PJ, Pfeifer PH, Ember JA, Hugli TE (1995) C3a is a chemotaxin for human eosinophils but not for neutrophils. I. C3a stimulation of neutrophils is secondary to eosinophil activation. J Exp Med 181:2119-2127

4. Nordahl EA, Rydengård V, Nyberg P, Nitsche DP, Mörgelin M, Malmsten M, Bjårck L, Schmidtchen A (2004) Activation of the complement system generates antibacterial peptides. Proc Natl Acad Sci USA 101:16879-16884

5. Gros P, Milder F, Janssen B (2008) Complement driven by conformational changes. Nat Rev Immunol 8:48-58

6. Borregaard N, Sørensen OE, Theilgaard-Mönch K (2007) Neutrophil granules: a library of innate immunity proteins. Trends Immunol 28:340-345

7. Blom AM, Hallström T, Riesbeck K (2009) Complement evasion strategies of pathogens - acquisition of inhibitors and beyond. Mol Immunol 46:2808-2817

8. Lambris JD, Ricklin D, Geisbrecht BV (2008) Complement evasion by human pathogens. Nat Rev Microbiol 6:132-142

9. Geisbrecht BV (2008) Staphylococcal complement inhibitors: biological functions, recognition of complement components, and potential therapeutic implications. Adv Exp Med Biol 632:221-236

10. Forsgren A, Sjoquist J (1966) "Protein A" from S. aureus. I. Pseudo-immune reaction with human gamma-globulin. J Immunol 97:822-827

11. Goward CR, Scawen MD, Murphy JP, Atkinson T (1993) Molecular evolution of bacterial cell-surface proteins. Trends Biochem Sci 18:136-140

12. Atkins KL, Burman JD, Chamberlain ES, Cooper JE, Poutrel B, Bagby S, Jenkins ATA, Feil EJ, Van den Elsen JMH (2008) S. aureus IgG-binding proteins $\mathrm{SpA}$ and Sbi: host specificity and mechanisms of immune complex formation. Mol Immunol 45:1600-1611

13. Rooijakkers SHM, van Wamel WJB, Ruyken M, van Kessel KPM, van Strijp JAG (2005) Anti-opsonic properties of staphylokinase. Microbes Infect 7:476-484

14. Collin M, Olsen A (2001) Effect of SpeB and EndoS from Streptococcus pyogenes on human immunoglobulins. Infect Immun 69:7187-7189

15. Collin M, Olsen A (2001) EndoS, a novel secreted protein from Streptococcus pyogenes with endoglycosidase activity on human IgG. EMBO J 20:3046-3055

16. Lukomski S, Burns EH, Wyde PR, Podbielski A, Rurangirwa J, Moore-Poveda DK, Musser JM (1998) Genetic inactivation of an extracellular cysteine protease (SpeB) expressed by Streptococcus pyogenes decreases resistance to phagocytosis and dissemination to organs. Infect Immun 66:771-776

17. Terao Y, Mori Y, Yamaguchi M, Shimizu Y, Ooe K, Hamada S, Kawabata S (2008) Group A streptococcal cysteine protease 
degrades $\mathrm{C} 3(\mathrm{C} 3 \mathrm{~b})$ and contributes to evasion of innate immunity. J Biol Chem 283:6253-6260

18. Hair PS, Ward MD, Semmes OJ, Foster TJ, Cunnion KM (2008) Staphylococcus aureus clumping factor A binds to complement regulator factor I and increases factor I cleavage of $\mathrm{C} 3 \mathrm{~b}$. J Infect Dis 198:125-133

19. Rooijakkers SHM, Ruyken M, Roos A, Daha MR, Presanis JS, Sim RB, van Willem JB, Wamel KPM, van Kessel J, van Strijp AG et al (2005) Immune evasion by a staphylococcal complement inhibitor that acts on C3 convertases. Nat Immunol 6:920-927

20. Rooijakkers SHM, Wu J, Ruyken M, van Domselaar R, Planken KL, Tzekou A, Ricklin D, Lambris JD, Janssen BJC, van Strijp JAG, Gros P (2009) Structural and functional implications of the alternative complement pathway C3 convertase stabilized by a staphylococcal inhibitor. Nat Immunol 10:721-727

21. Ricklin D, Tzekou A, Garcia BL, Hammel M, McWhorter WJ, Sfyroera G, Wu Y, Holers M, Herbert AP, Barlow PN, Geisbrecht BV, Lambris JD (2009) A molecular insight into complement evasion by the staphylococcal complement inhibitor protein family. J Immunol 183:2565-2574

22. Jongerius I, Köhl J, Pandey MK, Ruyken M, Van Kessel KPM, Van Strijp JAG, Rooijakkers SHM (2007) Staphylococcal complement evasion by various convertase-blocking molecules. J Exp Med 204:2461-2471

23. Hammel M, Sfyroera G, Ricklin D, Magotti P, Lambris JD, Geisbrecht BV (2007) A structural basis for complement inhibition by Staphylococcus aureus. Nat Immunol 8:430-437

24. Hammel M, Sfyroera G, Pyrpassopoulos S, Ricklin D, Ramyar KX, Pop M, Jin Z, Lambris JD, Geisbrecht BV (2007) Characterization of Ehp, a secreted complement inhibitory protein from Staphylococcus aureus. J Biol Chem 282:30051-30061

25. Ricklin D, Ricklin-Lichtsteiner SK, Markiewski MM, Geisbrecht BV, Lambris JD (2008) Cutting edge: members of the Staphylococcus aureus extracellular fibrinogen-binding protein family inhibit the interaction of $\mathrm{C} 3 \mathrm{~d}$ with complement receptor 2 . J Immunol 181:7463-7467

26. Burman JD, Leung E, Atkins KL, O'Seaghdha MN, Lango L, Bernardo P, Bagby S, Svergun DI, Foster TJ, Isenman DE, van den Elsen JM (2008) Interaction of human complement with Sbi, a staphylococcal immunoglobulin-binding protein: indications of a novel mechanism of complement evasion by Staphylococcus aureus. J Biol Chem 283:17579-17593

27. Haupt K, Reuter M, van den Elsen J, Burman J, Halbich S, Richter J, Skerka C, Zipfel PF (2008) The Staphylococcus aureus protein Sbi acts as a complement inhibitor and forms a tripartite complex with host complement Factor $\mathrm{H}$ and C3b. PLoS Pathog 4:e1000250

28. Robinson JH, Kehoe MA (1992) Group A streptococcal M proteins: virulence factors and protective antigens. Immunol Today 13:362-367

29. Fischetti VA (1989) Streptococcal M protein: molecular design and biological behavior. Clin Microbiol Rev 2:285-314

30. McNamara C, Zinkernagel AS, Macheboeuf P, Cunningham MW, Nizet V, Ghosh P (2008) Coiled-coil irregularities and instabilities in group A Streptococcus M1 are required for virulence. Science 319:1405-1408

31. Kotarsky H, Hellwage J, Johnsson E, Skerka C, Svensson HG, Lindahl G, Sjobring U, Zipfel PF (1998) Identification of a domain in human factor $\mathrm{H}$ and factor $\mathrm{H}$-like protein-1 required for the interaction with streptococcal M proteins. J Immunol 160: 3349-3354

32. Johnsson E, Thern A, Dahlback B, Heden LO, Wikstrom M, Lindahl G (1996) A highly variable region in members of the streptococcal $\mathrm{M}$ protein family binds the human complement regulator C4BP. J Immunol 157:3021-3029

33. Carlsson F, Berggard K, Stalhammar-Carlemalm M, Lindahl G (2003) Evasion of phagocytosis through cooperation between two ligand-binding regions in Streptococcus pyogenes $\mathrm{M}$ protein. $\mathrm{J}$ Exp Med 198:1057-1068

34. Ashbaugh CD, Warren HB, Carey VJ, Wessels MR (1998) Molecular analysis of the role of the group A streptococcal cysteine protease, hyaluronic acid capsule, and $\mathrm{M}$ protein in a murine model of human invasive soft-tissue infection. J Clin Invest $102: 550-560$

35. Tsao N, Tsai W, Lin Y, Chuang W, Wang C, Kuo C (2006) Streptococcal pyrogenic exotoxin B cleaves properdin and inhibits complement-mediated opsonophagocytosis. Biochem Biophys Res Commun 339:779-784

36. Langley R, Wines B, Willoughby N, Basu I, Proft T, Fraser JD (2005) The staphylococcal superantigen-like protein 7 binds IgA and complement $\mathrm{C} 5$ and inhibits IgA-Fc alpha RI binding and serum killing of bacteria. J Immunol 174:2926-2933

37. Wexler DE, Chenoweth DE, Cleary PP (1985) Mechanism of action of the group A streptococcal C5a inactivator. Proc Natl Acad Sci USA 82:8144-8148

38. Husmann LK, Yung DL, Hollingshead SK, Scott JR (1997) Role of putative virulence factors of Streptococcus pyogenes in mouse models of long-term throat colonization and pneumonia. Infect Immun 65:1422-1430

39. Postma B, Kleibeuker W, Poppelier MJJG, Boonstra M, Van Kessel KPM, Van Strijp JAG, De Haas CJC (2005) Residues 10 18 within the $\mathrm{C} 5$ a receptor $\mathrm{N}$ terminus compose a binding domain for chemotaxis inhibitory protein of Staphylococcus aureus. J Biol Chem 280:2020-2027

40. Ippel JH, De Haas CJC, Bunschoten A, Van Strijp JAG, Kruijtzer JAW, Liskamp RMJ, Kemmink J (2009) Structure of the tyrosinesulfated $\mathrm{C} 5 \mathrm{a}$ receptor $\mathrm{N}$ terminus in complex with chemotaxis inhibitory protein of Staphylococcus aureus. J Biol Chem 284: 12363-12372

41. Fernie-King BA, Seilly DJ, Davies A, Lachmann PJ (2001) Streptococcal inhibitor of complement (SIC) inhibits the membrane attack complex by preventing uptake of C567 onto cell membranes. Immunology 103:390-398

42. Frick IM, Akesson P, Rasmussen M, Schmidtchen A, Björck L (2003) SIC, a secreted protein of Streptococcus pyogenes that inactivates antibacterial peptides. J Biol Chem 278:16561-16566

43. Sjoberg AP, Trouw LA, Blom AM (2009) Complement activation and inhibition: a delicate balance. Trends Immunol 30:83-90

44. de Haas CJC, Veldkamp KE, Peschel A, Weerkamp F, Van Wamel WJB, Heezius EC, Poppelier MJ, Van Kessel KP, Van Strijp JAG (2004) Chemotaxis inhibitory protein of Staphylococcus aureus, a bacterial antiinflammatory agent. J Exp Med 199:687-695

45. Gladysheva IP, Turner RB, Sazonova IY, Liu L, Reed GL (2003) Coevolutionary patterns in plasminogen activation. Proc Natl Acad Sci USA 100:9168-9172

46. Haas PJ, de Haas CJC, Kleibeuker W, Poppelier MJ, Van Kessel KPM, Kruijtzer JA, Liskamp RM, Van Strijp JAG (2004) Nterminal residues of the chemotaxis inhibitory protein of Staphylococcus aureus are essential for blocking formylated peptide receptor but not C5a receptor. J Immunol 173:5704-5711

47. Kimura Y, Miwa T, Zhou L, Song WC (2008) Activator-specific requirement of properdin in the initiation and amplification of the alternative pathway complement. Blood 111:732-740

48. Hourcade DE (2006) The role of properdin in the assembly of the alternative pathway $\mathrm{C} 3$ convertases of complement. J Biol Chem 281:2128-2132 